\title{
POSTOPERATIVE PAIN MANAGEMENT AFTER CARPAL TUNNEL SYNDROME SURGICAL TREATMENT: COMPARING PRACTICE WITH GUIDELINES
}

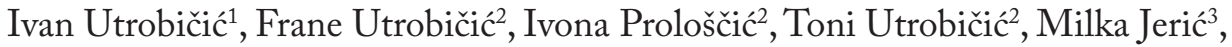 \\ Antonia Jeličić Kadić ${ }^{2,4}$ and Livia Puljak ${ }^{2}$
}

${ }^{1}$ Department of Plastic Surgery, Split University Hospital Center; ${ }^{2}$ Laboratory for Pain Research, School of Medicine, University of Split, Split; ${ }^{3}$ Department of Dermatovenereology, Zadar General Hospital, Zadar; ${ }^{4}$ Clinical Department of Pediatrics, Split University Hospital Center, Split, Croatia

\begin{abstract}
SUMMARY - The management of postoperative pain after carpal tunnel syndrome surgical treatment at a tertiary hospital was analyzed and compared with the guidelines for perioperative pain management. This retrospective study included 579 patients operated on for carpal tunnel syndrome at the Split University Hospital Center in Split, Croatia. The following key data were collected from patient medical records: age, gender, type and dosage of premedication, type and dosage of anesthesia, type and dosage of postoperative analgesia per each postoperative day. The procedures related to perioperative pain were analyzed and compared with the current guidelines for perioperative acute pain management. Study results showed that $99.6 \%$ of patients with carpal tunnel syndrome were operated under local anesthesia, of which $2.9 \%$ also received sedation. Analgesics were prescribed to $45 \%$ of patients after surgery, and according to patient charts, $39 \%$ of patients actually received postoperative analgesic(s). Generally, postoperative pain was treated on the first postoperative day, mostly with nonsteroidal anti-inflammatory drugs. Only two patients received weak opioids for postoperative pain. Many recommendations from the guidelines for perioperative acute pain management were not followed. In conclusion, the guidelines should be followed and appropriate interventions used to improve postoperative pain management.

Key words: Pain, postoperative; Carpal tunnel syndrome; Pain management; Analgesia; Anesthesia, local; Anti-inflammatory agents, non-steroidal; Croatia
\end{abstract}

\section{Introduction}

Despite the ever-greater focus on the treatment of pain after surgery, many very recent reports indicate the lack of attention to postoperative pain intensity and postoperative analgesia in various settings and operative procedures ${ }^{1-4}$. Inadequate perioperative pain management results in adverse clinical outcomes, additional time spent in intensive care units, and hospital

Correspondence to: Prof. Livia Puljak, $M D, P h D$, Laboratory for Pain Research, School of Medicine, University of Split, Šoltanska 2, HR-21000 Split, Croatia

E-mail:1ivia@mefst.hr

Received November 24, 2016, accepted July 19, 2017 readmissions for further pain management ${ }^{5}$. Furthermore, postoperative acute pain is an important factor contributing to the development of chronic pain. Adequate perioperative analgesia reduces the risk of chronic pain. Effective postoperative analgesia is known to be of major importance for preventing postoperative chronic pain ${ }^{6,7}$.

The fact that postoperative pain is often neglected in spite of its severity and high prevalence is bewildering since there is ample reliable evidence on the analgesic efficacy of multiple modes of analgesia, even as single dose oral analgesics ${ }^{8}$. There is also evidence that regional anesthesia can prevent chronic pain after surgery ${ }^{9}$. 
It has been suggested in medical literature that the postoperative course after carpal tunnel syndrome surgery is seldom complicated by severe postoperative pain $^{10-13}$. However, few studies analyzed pain incidence and postoperative pain control among patients undergoing carpal tunnel syndrome surgery ${ }^{14}$. For example, Orak et al. have recently reported that open surgery of carpal tunnel syndrome leads to average pain intensity above 5 on the visual analog scale (VAS), with some patients indicating that they suffered the worst imaginable pain intensity ${ }^{15}$.

However, it has been well documented that carpal tunnel syndrome surgery can lead to prevalent chronic postoperative pain. In 2015, a study of the outcomes of carpal tunnel release surgery indicated that $18 \%$ of patients had residual pain at 1-month postoperative follow-up ${ }^{10}$. In a study of limited carpal tunnel release, pillar pain was found in $48 \%$ of hands at four weeks, $21 \%$ at 12 weeks, $12 \%$ at six months, $9 \%$ at 12 months and $7 \%$ at the 18 -month follow-up ${ }^{16}$.

Better perioperative pain management may prevent the onset of chronic pain and improve patient function, quality of life, and satisfaction following carpal tunnel syndrome surgery. Comparing actual practice with modalities of perioperative pain management addressed in the recommended practice can provide recommendations to improve the carpal tunnel syndrome management, perioperative patient care and quality of life in patients with acute and chronic pain ${ }^{5}$.

The aim of this study was to analyze the management of postoperative pain after carpal tunnel syndrome surgical treatment in a tertiary hospital and to compare it with the guidelines for perioperative pain management.

\section{Patients and Methods}

The study protocol was approved by the Ethics Committee of the Split University Hospital Center in Split, Croatia. The study was conducted at the tertiary medical center, Split University Hospital Center in Split, Croatia. This was a retrospective study and data were collected from the archived hospital patient records.

\section{Patients}

Adult patients (age $\geq 18$ years) having undergone carpal tunnel release surgery at the Department of
Plastic Surgery, Split University Hospital Center between January 2007 and December 2015 were included in this retrospective observational study ( $N=579)$. Inclusion criteria were idiopathic and secondary carpal tunnel syndrome, whereas benign tumors such as lipoma, ganglion, and vascular malformation were exclusion criteria. Diagnosis of carpal tunnel syndrome in each patient was based on the history, clinical symptoms (pain, tingling, numbness, reducing power grip, reduction of fine motor skills), clinical tests (Tinel's and Phallen's tests) and electroneurography.

\section{Operative procedure}

Surgical patients are routinely admitted to the hospital on the day of surgery or the day before. Carpal tunnel release was performed under local infiltration anesthesia performed with $2 \%$ lidocaine in a total volume of $10 \mathrm{~mL}$ on outpatient basis. Carpal tunnel decompression surgery was performed by different surgeons using the same operative procedure of open type of carpal tunnel release. An incision of $4 \mathrm{~cm}$ long, 2 $\mathrm{mm}$ ulnar to the thenar crease line and distal to the Kaplan oblique line was made. The superficial palmar fascia and the transverse carpal ligament were cut through the ulnar side. The skin and subcutaneous tissue were released proximally and distally with a retractor, and then the opening of the tunnel was confirmed. The skin was closed in a single phase, with separate stitches using non-absorbable sutures. In postoperative care, patients are usually given analgesics by oral administration. Patients were discharged a few hours to one day after the surgery, with prescription for analgesics. A bandage was fitted and left in place for 10 days.

\section{Variables}

The following data were collected from patient medical records: age, gender, type and dosage of premedication, type of procedure, operator, duration of procedure (operating and anesthesia time), type and dosage of anesthesia, type and dosage of postoperative analgesia per each postoperative day. Data on all medications taken by patients during hospital stay, recorded in patient records, were extracted.

To compare perioperative pain practice in carpal tunnel syndrome surgery with the guidelines ${ }^{5}$, the following data were also examined for the 9-year study 
period: provision of continuous education by anesthesiologists to healthcare workers involved in postoperative care at the Department of Plastic Surgery; documented information on preoperative pain intensity in patient medical records; asking about postoperative pain intensity and pain intensity measuring tools; documented therapy effects on pain and adverse events associated with analgesics; usage of multimodal measures for pain management (using at least two analgesics with different mechanisms of action); first analgesic intake; total dose of postoperative medication in the first $24 \mathrm{~h}$; whether patients were prescribed acetaminophen for pain management; and whether patients had intensive monitoring after surgery. Data on the institutional guidelines and practices were gathered from the anesthesiologists and plastic surgeons affiliated with the department.

\section{Statistics}

Data were analyzed using descriptive statistics and expressed as frequencies and percentages, mean and standard deviation $(\mathrm{M} \pm \mathrm{SD})$ or median and range, where appropriate. Microsoft Excel formulas were used for descriptive statistics (Microsoft Inc., Redmond, WA, USA).

\section{Results}

During the 9-year study period, 579 patients underwent surgery due to carpal tunnel syndrome. There were 133 (23\%) men and 446 (77\%) women. Average age of patients was $58 \pm 12$ years, with the youngest patient aged 26 and the oldest 88 years. Six surgeons performed the surgical procedures. Median duration of hospital stay was 2 days (range: 1-6 days).

Analysis of therapy indicated in patient charts revealed discrepancies between prescribed pharmacological therapy and therapy that was actually administered to patients. Patient charts indicated that physicians recommended preoperative pharmacological therapy for $17 / 579$ (2.9\%) patients, where 16 patients received prescription for an analgesic or a sedative. Of those 16 patients, two patients were prescribed the analgesic metamizole and 14 patients were prescribed sedation, with diazepam prescribed to three patients, midazolam to five patients, and a combination of diazepam and midazolam to six patients.
Table 1. Postoperative analgesia recommended

\begin{tabular}{|l|c|}
\hline Drug(s) & $\mathrm{n}(\%)$ of patients \\
\hline Metamizole & $240(41)$ \\
Ibuprofen & $7(1.2)$ \\
Diclofenac & $3(0.5)$ \\
Analgesic* & $2(0.3)$ \\
Ketoprofen & $1(0.2)$ \\
Metamizole and diclofenac & $5(0.8)$ \\
Metamizole and tramadol & $1(0.2)$ \\
Metamizole, diclofenac and tramadol & $1(0.2)$ \\
\hline
\end{tabular}

*For two patients, only 'analgesic' was written on the patient chart as the physician's instruction

In $23(4.5 \%)$ patients, their charts indicated that they had actually received an analgesic or a sedative as preoperative pharmacological intervention. Six patients received an analgesic preoperatively: four patients received metamizole, one patient received ibuprofen, and one patient received both metamizole and ibuprofen. Seventeen patients received a sedative agent preoperatively: eight patients received diazepam, five patients received midazolam, and four patients received both diazepam and midazolam.

Only three patients received certain preoperative drugs (ibuprofen, diazepam and midazolam) twice; all other drugs were taken as a single preoperative dose. Fourteen of these patients received those drugs on the day before surgery, whereas nine patients received a drug (midazolam all) on the day of surgery.

Of 579 patients, two patients were operated under general anesthesia, whereas 577 patients were operated under local anesthesia using $10 \mathrm{~mL}$ of $2 \%$ lidocaine. Duration of operation was noted for 33 (5.8\%) patients. Median duration of surgical procedure was 30 minutes (range: 20-60 min).

According to patient charts, physicians recommended that postoperative analgesic(s) should be given to $260 / 579$ (45\%) patients (Table 1 ).

There were 223/579 (39\%) patients who actually received postoperative analgesic(s), according to the patient charts. Most of them received the analgesic metamizole as a single dose only on the day of surgery (Table 2). Of 223 patients, 140 (63\%) received single dose of analgesic; 149 (67\%) received analgesic(s) only on the day of surgery, 28 (13\%) only on postoperative day 1 , nine $(4 \%)$ on postoperative day 2 , three $(1.3 \%)$ 
Table 2. Postoperative analgesia received

\begin{tabular}{|l|c|}
\hline Drug(s) & $\mathrm{n}(\%)$ of patients \\
\hline Metamizole & $145(25)$ \\
Pill & $137(24)$ \\
i.v. ampoule & $5(0.8)$ \\
Pill and i.v. ampoule & $3(0.5)$ \\
Ibuprofen & $38(6.5)$ \\
Ketoprofen & $14(2.4)$ \\
Diclofenac & $6(1)$ \\
Acetaminophen & $1(0.2)$ \\
Tramadol & $1(0.2)$ \\
Metamizole and ibuprofen & $9(1.6)$ \\
Metamizole and diclofenac & $3(0.5)$ \\
Metamizole and ketoprofen & $3(0.5)$ \\
Ibuprofen and ketoprofen & $1(0.2)$ \\
Metamizole and acetaminophen & $1(0.2)$ \\
Metamizole, diclofenac and tramadol & $1(0.2)$ \\
\hline
\end{tabular}

on postoperative day 3 , and two $(0.9 \%)$ only on postoperative day 5 .

In the letter of discharge, 251/579 (43\%) patients received recommendation for further therapy. Of those patients, one patient received instruction to take an antihypertensive drug, 11 patients were instructed to take 'analgesics', and 239 patients were instructed to take vitamin B complex and analgesics.

There are no institutional guidelines for acute pain management in the analyzed hospital. Not a single patient medical record contained information on preoperative or postoperative pain intensity. None of the patient medical records had any information on adverse events associated with analgesics. Multimodal measures for pain management were not used and acetaminophen was very rarely used for postoperative pain management.

\section{Discussion}

Our study showed that most of the patients with carpal tunnel syndrome had been operated under local anesthesia and that postoperative pain management may have been inadequate since only $39 \%$ of patients actually had received postoperative analgesic(s), according to patient charts.

It is long known that pain is one of the most frequently reported postoperative symptoms ${ }^{17}$. A recent
US study analyzed the efficacy of postoperative pain management, and based on 441 surgical inpatients from different medical departments, it was reported that $12 \%$ of patients had severe to extreme pain, while $54 \%$ of patients reported having moderate to extreme pain at discharge. During the first 14 days after surgery, there were $13 \%$ of patients with severe to extreme pain, and $46 \%$ suffering moderate to extreme pain. These data indicate a very high prevalence of intensive postoperative pain, and similar results have been reported for many different types of surgical procedures $^{18}$.

It is known that the lack of adequate postoperative pain treatment may lead to chronic postoperative pain (CPOP), which is often overlooked. Inadequate pain management also increases health care costs due to the increased use of health care resources ${ }^{19}$. In 2012, Belze et al. published a study about the incidence of CPOP after carpal tunnel surgery, evolution of nocturnal and diurnal pains during the year following the surgery, and epidemiological factors associated with this pain. They report that nocturnal and diurnal pains disappeared in $55 \%$ and $50 \%$ of patients, respectively, on the evening of the procedure. One year after the surgery, $12 \%$ of patients complained of pain similar to the preoperative pain and $22 \%$ of patients complained of a new pain, which was different from the pain experienced before the surgery, thus being considered as CPOP. The key finding of this study was that postoperative pain was significantly associated with CPOP, as well as the absence of hypnotic approach during surgery $^{20}$.

There are variable reports on the incidence of $\mathrm{CPOP}$ after major surgical procedures, ranging from $20 \%$ to $50 \%^{21-23}$. The incidence of CPOP after major orthopedic surgical procedures ranges from $8 \%$ to $25 \%$ for hip replacement ${ }^{24}$, and from $19 \%$ to $47 \%$ for knee replacement ${ }^{25}$. Therefore, we conclude that the incidence of CPOP of $22 \%$ after carpal tunnel surgery is comparable to the incidence for major surgeries in orthopedics. Thus, since postoperative pain is a major contributing factor to the development of CPOP, adequate postoperative pain management should be a priority for healthcare staff caring for patients after carpal tunnel surgery.

In our study, we analyzed both physicians' instructions related to postoperative analgesia and the records demonstrating that patients had really received the an- 
algesic. We found that physicians had recommended analgesic(s) to $45 \%$ of patients, which means that a portion of patients supposed to get analgesic according to the physician's instruction did not actually get it. $\mathrm{Pa}-$ tient charts did not allow any conclusions about the question why physicians did not recommend an analgesic to $55 \%$ of patients.

It is known that there are multiple factors involved in inadequate perioperative pain management. One of these factors is division of care. In this setting, pain medication after surgery is prescribed by an attending surgeon and administered by a nurse. While prescribing pain medication, the physicians may have little or no information on pain intensity that patients actually experience and they may believe that patients are not in pain unless they complain. However, the experience of pain is individual and patients may behave very differently towards pain; they may not verbally express pain intensity they are experiencing. It has also been indicated in the literature that health professionals may believe that pain is inevitable and normal after surgery, and that it will pass eventually ${ }^{1}$.

A recent US study about trends in carpal tunnel surgery by members of the American Society of Surgeons of the Hand indicated that in terms of anesthesia, intravenous sedation with local anesthesia was the most common practice (43\%), followed by Bier block (18\%). Postoperative pain management is described as variable, with hydrocodone and derivatives administered most commonly $(61 \%)^{26}$.

In our study, almost all patients were operated under local anesthesia, whereas only 17/579 (2.9\%) patients actually received sedation together with local anesthesia. Postoperative pain was treated almost exclusively with nonsteroidal anti-inflammatory drugs (NSAIDs); only two patients received a weak opioid tramadol as the only postoperative analgesic and in combination with NSAIDs in one patient each. A recent overview of Cochrane reviews has indicated that the existing systematic reviews provide reliable evidence for the analgesic efficacy of single dose oral analgesics for acute postoperative pain in adults. The overview concludes that fast acting formulations and fixed dose combinations of analgesics can produce adequate and often long-lasting analgesia at relatively low doses ${ }^{8}$.

Since none of the patient charts in our study included information on preoperative or postoperative pain intensity, it is highly likely that none of the patients had been asked about their pain intensity in order to provide personalized pain management according to their needs.

Our results were compared with the latest version of guidelines for acute perioperative pain management, which indicate that there should be institutional guidelines addressing six main components, including education of staff, monitoring of patient outcomes, documentation of monitoring, monitoring of outcomes at an institutional level, anesthesiologists available $24 \mathrm{~h}$ to provide perioperative pain management, and use of a dedicated acute pain service ${ }^{5}$. None of these was present in the hospital analyzed in this study.

Therefore, there are a number of interventions that could be introduced to improve postoperative pain management in carpal tunnel surgery in this hospital. Surgeons and nurses should receive training about the importance of postoperative pain management and appropriate measures for pain treatment. Pain intensity should be monitored both preoperatively and postoperatively, and recorded in patient charts. Pain assessment in clinical practice is a simple task in daily routine ${ }^{27,28}$. Institutional guidelines for acute pain management should be implemented, and anesthesiologists specialized in pain management should have the leading role in these changes. Without adequate analgesia, patients may engage in negative practices of self-medicating and sharing prescription analgesics ${ }^{29,30}$.

There were several limitations to this study, including retrospective design and limited data available in patient charts. Since pain intensity was not recorded, it may be difficult to judge whether pain management was adequate, but it is difficult to conceive that as many as $61 \%$ of patients who did not get an analgesic postoperatively had been free from any postoperative pain.

In conclusion, postoperative pain management in patients undergoing carpal tunnel syndrome surgery in the analyzed setting was inadequate. Appropriate interventions need to be used to improve postoperative pain management, facilitate patient recovery, and prevent development of chronic postoperative pain.

\section{References}

1. Lesin M, Sundov ZD, Jukic M, Puljak L. Postoperative pain in complex ophthalmic surgical procedures: comparing practice 
with guidelines. Pain Med. 2014;15(6):1036-42. doi: 10.1111/ pme. 12433

2. Rafati F, Soltaninejad M, Aflatoonian MR, Mashayekhi F. Postoperative pain: management and documentation by Iranian nurses. Mater Sociomed. 2016;28(1):36-40. doi: 10.5455/ msm.2016.28.36-40

3. Liu D, Ma J, Zhang Z, et al. Management of postoperative pain in medical institutions in Shandong Province in China. Medicine (Baltimore). 2016;95(6):e2690. doi: 10.1097/MD.00000 00000002690

4. Ahmed A, Yasir M. Role of acute pain service in optimizing postoperative pain relief in a tertiary care teaching hospital. J Pak Med Assoc. 2015;65(11):1164-8. doi: 10.4103/09709185.169074

5. Practice guidelines for acute pain management in the perioperative setting: an updated report by the American Society of Anesthesiologists Task Force on Acute Pain Management. Anesthesiology. 2012;116(2):248-73. doi: 10.1097/ALN.0b0 $13 \mathrm{e} 31823 \mathrm{c} 1030$

6. Poleshuck EL, Katz J, Andrus CH, et al. Risk factors for chronic pain following breast cancer surgery: a prospective study. J Pain. 2006;7(9):626-34. doi: 10.1016/j.jpain.2006.02.007

7. Sng BL, Sia AT, Quek K, Woo D, Lim Y. Incidence and risk factors for chronic pain after caesarean section under spinal anaesthesia. Anaesth Intensive Care. 2009;37(5):748-52. PMID: 19775038

8. Moore RA, Derry S, Aldington D, Wiffen PJ. Single dose oral analgesics for acute postoperative pain in adults - an overview of Cochrane reviews. Cochrane Database Syst Rev. 2015; 9:CD008659. doi: 10.1002/14651858.CD008659.pub3

9. Andreae MH, Andreae DA. Local anaesthetics and regional anaesthesia for preventing chronic pain after surgery. Cochrane Database Syst Rev. 2012;10:CD007105. doi: 10.1002/1465 1858.CD007105.pub2

10. Khan AA, Ali H, Ali K, et al. Outcome of open carpal tunnel release surgery. J Ayub Med Coll Abbottabad. 2015;27(3): 640-2. PMID: 26721028

11. Vanni D, Sirabella FS, Galzio R, Salini V, Magliani V. The double tunnels technique: an alternative minimally invasive approach for carpal tunnel syndrome. J Neurosurg. 2015; 123(5):1230-7. doi: 10.3171/2014.11.JNS14901

12. Ozer H, Solak S, Oguz T, Ocguder A, Colakoglu T, Babacan A. Alkalinisation of local anaesthetics prescribed for pain relief after surgical decompression of carpal tunnel syndrome. J Orthop Surg (Hong Kong). 2005;13(3):285-9. doi: 10.1177/ 230949900501300312

13. Reuben SS, Duprat KM. Comparison of wound infiltration with ketorolac versus intravenous regional anesthesia with ketorolac for postoperative analgesia following ambulatory hand surgery. Reg Anesth. 1996;21(6):565-8.

14. Palmaro A, Fuzier R, Serres I, Bourrel R, Lapeyre-Mestre M. Analgesic drug consumption increases after carpal tunnel surgery: a pharmacoepidemiological study investigating postop- erative pain. Clin Ther. 2015;37(8):e64-e65. doi: 10.1016/j. clinthera.2015.05.194

15. Orak MM, Gumustas SA, Onay T, Uludag S, Bulut G, Boru UT. Comparison of postoperative pain after open and endoscopic carpal tunnel release: a randomized controlled study. Indian J Orthop. 2016;50(1):65-9. doi: 10.4103/0019-5413. 173509

16. Yung PS, Hung LK, Tong CW, Ho PC. Carpal tunnel release with a limited palmar incision: clinical results and pillar pain at 18 month follow-up. Hand Surg. 2005;10(1):29-35. doi: 10.1142/S0218810405002413

17. Chung F, Un V, Su J. Postoperative symptoms 24 hours after ambulatory anaesthesia. Can J Anaesth. 1996;43(11):1121-7. doi: 10.1007/BF03011838

18. Buvanendran A, Fiala J, Patel KA, Golden AD, Moric M, Kroin JS. The incidence and severity of postoperative pain following inpatient surgery. Pain Med. 2015;16(12):2277-83. doi: 10.1111/pme. 12751

19. Joshi GP, Ogunnaike BO. Consequences of inadequate postoperative pain relief and chronic persistent postoperative pain. Anesthesiol Clin North Am. 2005;23(1):21-36. doi: 10.1016/j. atc.2004.11.013

20. Belze O, Remerand F, Laulan J, et al. Chronic pain after carpal tunnel surgery: epidemiology and associated factors. Ann Fr Anesth Reanim. 2012;31(12):e269-74. doi: 10.1016/j.annfar.2012.08.009

21. Kehlet H, Jensen TS, Woolf CJ. Persistent postsurgical pain: risk factors and prevention. Lancet. 2006;367(9522):1618-25. doi: 10.1016/S0140-6736(06)68700-X

22. Macrae WA. Chronic post-surgical pain: 10 years on. Br J Anaesth. 2008;101(1):77-86. doi: 10.1093/bja/aen099

23. Niraj G, Rowbotham DJ. Persistent postoperative pain: where are we now? Br J Anaesth. 2011;107(1):25-9. doi: 10.1093/bja/ aer116

24. Nikolajsen L, Brandsborg B, Lucht U, Jensen TS, Kehlet H. Chronic pain following total hip arthroplasty: a nationwide questionnaire study. Acta Anaesthesiol Scand. 2006;50(4): 495-500. doi: 10.1111/j.1399-6576.2006.00976.x

25. Petersen KK, Simonsen O, Laursen MB, Nielsen TA, Rasmussen S, Arendt-Nielsen L. Chronic postoperative pain after primary and revision total knee arthroplasty. Clin J Pain. 2015; 31(1):1-6. doi: 10.1097/AJP.0000000000000146

26. Munns JJ, Awan HM. Trends in carpal tunnel surgery: an online survey of members of the American Society for Surgery of the Hand. J Hand Surg Am. 2015;40(4):767-71 e762. doi: 10.1016/j.jhsa.2014.12.046

27. Lončarić-Katušin M, Milošević M, Žilić A, Mišković P, Majerić-Kogler V, Žunić J. Practical chronic pain assessment tools in clinical practice. Acta Clin Croat. 2016;55 Suppl 1: 19-26. doi: 10.20471/acc.2016.55.s1.02

28. Kontić M, Vičić-Hudorović V, Hudorović N. Treatment of postherpetic neuralgia with $5 \%$ topical lidocaine plaster - experience from a small county hospital: case report. Acta Clin Croat. 2016;55(4):655-8. doi: 10.20471/acc.2016.55.04.18 
29. Markotić F, Vrdoljak D, Puljiz M, Puljak L. Risk perception about medication sharing among patients: a focus group qualitative study on borrowing and lending of prescription analgesics. J Pain Res. 2017;10:365-74. doi: 10.2147/JPR.S123554
30. Markotić F, Puljak L. Risks associated with borrowing and sharing of prescription analgesics among patients observed by pain management physicians in Croatia: a qualitative study. J Pain Res. 2016;9:1143-51. doi: 10.2147/JPR.S118945

Sažetak

\section{POSLIJEOPERACIJSKO LIJEČENJE BOLI NAKON KIRURŠKOG LIJEČENJA SINDROMA KARPALNOG TUNELA: USPOREDBA PRAKSE SA SMJERNICAMA}

\section{Utrobičic, F. Utrobičic, I. Prološčic, T. Utrobičic, M. Jerić, A. Jeličič Kadić i L. Puljak}

Analizirali smo liječenje poslijeoperacijske boli nakon kirurškog liječenja sindroma karpalnog tunela u tercijarnoj bolnici i usporedili ga sa smjernicama za liječenje perioperacijske boli. Proveli smo retrospektivnu studiju u koju je bilo uključeno 579 bolesnika koji su operirani zbog sindroma karpalnog tunela u Kliničkom bolničkom centru Split, Hrvatska. Prikupljeni su sljedeći podatci iz povijesti bolesti: dob, spol, vrsta i doza premedikacije, vrsta i doza anestezije, vrsta i doza poslijeoperacijske analgezije za svaki poslijeoperacijski dan. Analizirani su postupci vezani za perioperacijsku bol i uspoređeni s važećim smjernicama. Rezultati su pokazali da je 99,6\% bolesnika operirano u lokalnoj anesteziji, a 2,9\% ih je uz to primilo sedaciju. Analgetici su propisani u $45 \%$ bolesnika nakon zahvata, a prema povijestima bolesti $39 \%$ bolesnika je analgetik zaista i dobilo. Poslijeoperacijska bol je liječena uglavnom samo prvog poslijeoperacijskog dana, većinom pomoću nesteroidnih protuupalnih lijekova. Samo je dvoje bolesnika dobilo slabi opioid za ublažavanje poslijeoperacijske boli. Brojne preporuke iz smjernica za perioperacijsko liječenje boli nisu se slijedile. Zaključno, nužno je slijediti smjernice i provesti prikladne intervencije kako bi se poboljšalo perioperacijsko liječenje boli.

Ključne riječi: Bol, poslijeoperacijska; Karpalni tunel, sindrom; Bol, liječenje; Analgezija; Anestezija, lokalna; Protuupalna sredstva, nesteroidna; Hrvatska 